\title{
GREEN INFRASTRUCTURE, A TOOL FOR STORM WATER MANAGEMENT: A CASE STUDY OF AKURE, ONDO STATE, NIGERIA
}

\author{
Aseyan Babajide Sunday ${ }^{1}$ and Ayeni Dorcas A. ${ }^{2}$ \\ ${ }^{1}$ Mr. Aseyan Babajide Sunday, Lead City University, Ibadan, NIGERIA, jdeestev@gmail.com \\ ${ }^{2}$ Dr. Ayeni Dorcas A., Department of Architecture, Federal University of Technology Akure, \\ NIGERIA.daayeni@futa.edu.ng; dorcasayeni2@yahoo.com
}

\begin{abstract}
Human activities have generated enormous pressure on the natural environment, resulting in several challenges such as flooding, pollution, and land degradation, orchestrated by poor city storm water management. Nevertheless, Green infrastructural (Gl) as a planning strategy offers promising opportunities in mitigating the effect of man on the environment. However, this strategy is usually affected by the low level of public awareness on its importance and methodology of operation, poor funding and policy inconsistency by state actors. This research aims to investigate Green infrastructure as a tool for storm water management by reviewing relevant articles and conducting a field case study on the selected areas in the city of Akure, a state in southwestern Nigeria. Assessment of the current state of storm water management was done by observing the level of the implementation of Gl. Qualitative content analysis was used to underscore the level of Gl implementation, identify the current situation and gaps from the literature, and analyze data input from the case studies. The paper identifies from the literature factors affecting storm water management, drawing a link between funding and the attitude of the state actors to change. Importantly it reveals that monitoring of the initiative is poor. Based on the findings, the study proposes future works on harnessing and congruent adoption of the benefit of $\mathrm{Gl}$ and other eco-friendly strategies to stimulate effective storm water management, among others. It recommends that conscious effort be made to engage stakeholders effectively in environmental management, such as government agencies saddled with responsibilities do their job promptly. Secondly, environmental experts must continually give awareness through periodic symposia's to educate the populace on the danger of poor storm water management to their wellness. Lastly, the people must own the initiative, through full participation in terms of implementation and even enforcement for any meaning success to be achieved. The paper identifies gaps in the literature showing that adequate attention has not been given to GI implementation in Nigeria, as in other clime cases. Consequently, the paper is a starting point towards more detailed research on storm management through the reliance on the principle of $\mathrm{Gl}$ to address the gaps in the existing knowledge.
\end{abstract}

Keywords: Storm water, Green infrastructure, Climate change, Urbanization. 


\section{INTRODUCTION}

In recent times, Green infrastructure has been identified as an alternative nature-based and cost-effective remedy to the incessant occurrence of climate change arising from human activities and improving the sustainability of urban development (Ely \& Pitman 2014; Lafortezza et al. 2013). The increasing urbanization is directly associated with the production and consumption of goods, services and infrastructure, which has resulted in greater land consumption by the built environment and as well translated to landscape fragmentation, biodiversity loss, urban heat islands, greenhouse gas emissions and the destruction of sensitive ecosystems (Pakzad and Osmond, 2015). Unambivalently, the combination of large populations, densely built structures and sealed surfaces seen in cities do not characterize ideal conditions for tackling a changing climate (Derkzen et al., 2017).

Demuzere et al. (2014) defines Green infrastructure (GI) as "infrastructure of green spaces, water and built systems, such as forests, wetlands, parks, green roofs and walls that together can contribute to ecosystem resilience and human benefits through ecosystem services". Also, The United States Environmental Protection Agency (USEPA, 2014) described GI as a "storm water management system that mimics the nature of soaking up and storing water, for instance, bio-retention (a well-known feature that creates 'rain gardens'), green roofs or green walls". Hence, a flood mitigation method through effective storm water channelization due to the capacity of its installations in engaging systems and practices that employ or mimic the natural processes, thereby allowing storm water to infiltrate, evaporate, runoff, and/or be used on-site (Liu et al., 2014).

The repercussions of urbanization on the environment have become increasingly alarming due to the impacts of heatwaves and heavy rainfall events emanating from the socioeconomic activity of human beings (European Economic Area, EEA, 2012). Meanwhile, Gao et al. (2015) and Intergovernmental Panel on Climate Change, IPCC (2014) asserted that a climate in which weather events become severe might lead to an increase in flooding, droughts and heat stress, causing not only financial damage but also threats to public health and safety. One of the challenges associated with storm water is pollution. For instance, Liu et al. (2014) noted that storm water as a result of runoff overload the municipal wastewater treatment works by carrying pollutants such as trash, bacteria and heavy metals into the receiving waters, thereby demeaning the quality of the urban stream meanwhile in an attempt of adopting the traditional approach in the management of storm water, storm water systems have become a channel for the deliveries of contaminated water into streams and rivers with a subsequent outcome such as polluted rivers and streams, health threats habitat degradation and increasing expense to maintain adequate systems (Cook, 2007).

However, despite GI gaining notoriety across Europe, America, Asia and the United Kingdom over some decades earlier (Bates, Sadler, Greswell and Mackay, 2015), coupled with being a strategic approach for effective management of storm water, their implicit use is still far from comprehension among Nigeria states in the sense that works of literature have not been able to establish its proper implementation considering the level of environmental issues still confronting Nigerian communities which could have been solved if adopted by built environment professionals in planning and design. To bridge the gap in knowledge, this study seeks to investigate Green infrastructure as a tool for storm water management in Akure, southwestern Nigeria, by assessing the level of implementation of Gls in the city layout of Akure metropolis and identifying constraints in Gl implementation

\subsection{Concept of Green Infrastructures}

Green infrastructure is an emerging idea linked to natural and designed ecosystems with the services they provide (Pakzad and Osmond, 2015) geared towards attaining a sustainable urban environment. Hence the diversities of definitions by social and environmental researchers. At the same time, planners view the concept in terms of policy implementation (Mell, 2010). The European Commission EU (2013) defined Green Infrastructure as 'a strategically planned network of high quality natural and semi-natural areas with other environmental features designed and managed to deliver a wide range of ecosystem services, and protect biodiversity in both rural and urban settings. Conversely, Tóth, Štěpánková and Feriancová (2016) described GI as a strategically planned system of natural and semi-natural areas, elements and green spaces in rural and urban environments with environmental elements designed and managed for providing a wide range of ecosystem functions and services (e.g., water regulation, which contributes not only to the environment, but also to human well-being and quality of life)".

Relative to the benefits accruable to human beings, the Australian Institute of Landscape Architects (AILA, 2012) describes green infrastructure as "a network of natural landscape assets which underpin the economic, socio-cultural and environmental functionality of cities and towns, that is, the green spaces and water systems which intersperse, connect, and provide vital life support for humans and other species within 
our urban environments." Thus, a multidimensional strategy with potentials for sustainable development.

GI serves as a medium for physical activity that promotes psychological health and mental well-being, reduces health inequality, and increases life expectancy (Forest Research, 2010). In addition, Promote economic growth and investment via job creation, business startup, increased land values and inward investment; Land regeneration by converting underused, neglected land in and around urban areas to green infrastructure; maintaining Wildlife by providing habitat for Species from the very common to the very rare to social inclusion and community cohesion by serving as a means of bringing people together. Distinctively, Derkzen et al. (2017) posited that Gl focuses on heat and flooding challenges arising from storm water runoff when considered from the point of climate adaptation perspective. Emphasizing the benefits, Artmann et al. (2019) and Church (2015) described GI as a nature-based adaptation for storm water control and management by supporting urban practitioners in structuring the complex interrelations between landscape planning and compact and green cities.

GI exists in diverse forms, Tóth et al. (2016) categorized GI as terrestrial (such as green spaces), aquatic ecosystems (such as blue spaces) and man-made elements, such as green rooms, eco-ducts, cycle routes, or restored natural areas. On a broader note, GI includes green roofs, green walls, gardens, grasses, shrubs, street trees, playgrounds, water plazas, small parks, canals, wooded parks, recreational parks, water-rich parks (Derkzen, Teeffelen \& Verburg, 2017). Green roofs are also known as vegetated roofs, ecoroofs, or living roofs, that comprises of engineered system with different layers of mosses, succulents, and herbs Calheiros and Stefanakis (2021) have been identified for their vital role in mitigating storm water runoff in urban areas due to its water retention capacity and the ability to conserve energy and increase improvement in the thermal performances of buildings system (Bevilacqua,Mazzeo, Bruno \&Arcuri, 2016; Feitosa \& Wilkinson, 2016).

Another type of $\mathrm{Gl}$ is green walls. They are described as a vertical garden commonly used in iconic buildings of public infrastructures in developed nations (Hindle, 2012). Coherently, McCullough, Martin and Sajady (2018) described green walls as vertical garden or living wall which involves substrate, live plants and a water delivery system serving as a channel of connecting to "outdoor nature" within the indoor environment. Invariably, built environment professionals and landscape planners must engage strategies that can support and promote sustainable urban development in the design and planning landscape.

\subsection{Green Infrastructure Strategy for Storm Water Management}

Storm water is defined as "extreme runoff from pervious and impervious surfaces that include roofs, driveways, pavements, footpaths, and roads infrastructure characteristic of urban areas" (Trincheria and Yemaneh 2016; Shafique. et al., 2018). Consequently, storm water runoff remains one of the causal factors of aquatic ecosystem degradation around the globe (Moore, Rodak, Ahmed and Voge, 2018). Meanwhile, studies have posited that the primary challenge to storm water management is not restricted to a solution based on pipe networks or the adoption of improved technology but on the development of working procedures and planning that engages actor collaborations. Barbosa, Fernandes \& David (2012) noted that GI Strategies required to actualize sustainability in storm water management are necessary at diverse decision-making levels for any meaningful success to be achieved. However, a clear understanding of the possibilities of the strategy and the consequences of each decision must come with reliable information on the methodology of achieving them.

Invariably, GI strategy for storm water management must be flexible, based on local characteristics considering temporal, spatial and administrative factors and law, among other issues (Barbosa et al., 2012). Therefore, more significant effort is expected to establish integrative urban monitoring concepts that capture built and natural structures and city stewardship by urban actors while considering the interactions between biophysical, social, and governance structures and processes (Pickett et al., 2016 and McPhearson et al., 2016). Therefore, built environment professionals need to develop and articulate aspirational strategies that gradually implement catchment-wide surface water flood management actions.

\section{METHODOLOGY}

\subsection{Study Area}

The study area is Oba Adesida road to Alagbaka road, in Akure South Local government Ondo State, Nigeria. Akure is a city in the South Western Nigerian Geopolitical zone. It is the largest city and the capital of Ondo State with a population of 484,798 during the last census of conducted in the year 2006. Akure city covers $991 \mathrm{sq} . \mathrm{km}$, with the highest elevation standing at $350 \mathrm{~m}(1,150 \mathrm{ft})$. The city lies along $7^{\circ} 25^{\prime}$ North and $5^{\circ} 19^{\prime}$ East meridian of the equator, it is situated in the tropical rainforest zone of Nigeria, with average annual 
rainfall of $1524 \mathrm{~mm}$ and the raining season lasting for 7 months between April and October. The difference in precipitation between the driest month and the wettest month is $386 \mathrm{~mm}$, with an average temperature of $27.5^{\circ} \mathrm{C}$ (Adeleke \& Olabode, 2017). The drainage pattern of akure is uncoordinated often draining to rivers such as, Ala, River Owena and Ogburugburu (Adeleke \& Olabode, 2017).

\subsection{Research Design}

This study adopted qualitative approach using an observational method for information gathering. The information gathered are presented by rational analyses of observed phenomena as expressed in qualitative terms. Observation method is a means of collecting data by taking into cognizance cause of action as it occurs. Emphasis was laid on taking detailed notes of the life situation as it affects storm water management and the causes in real time.

\subsection{Result and Discussions}

On a global scale, discussion around the topic (storm water management) is becoming a recurrent denominator because of its impact on the ecosystem. Green infrastructure has a strategic environmental plan that becomes a viable option, owing to its ecological importance. Meanwhile, a view of the study area shows some level of green infrastructural implementation, particularly in the area of storm water management, however, the success recorded is at variance because of the way the strategy had been managed. These vagaries to Gl implementation in the study area are traceable to several factors vis-à-vis: inadequate funding of the green strategy, low level of awareness of environmental control principles of the populace, lack of maintenance of public assets and above all policy inconsistency by successive governments in Ondo state, and of course Nigeria in general.

The figures below describe the level of Gl implementation in the study area and the enormity of the strategy's challenges in perspective.

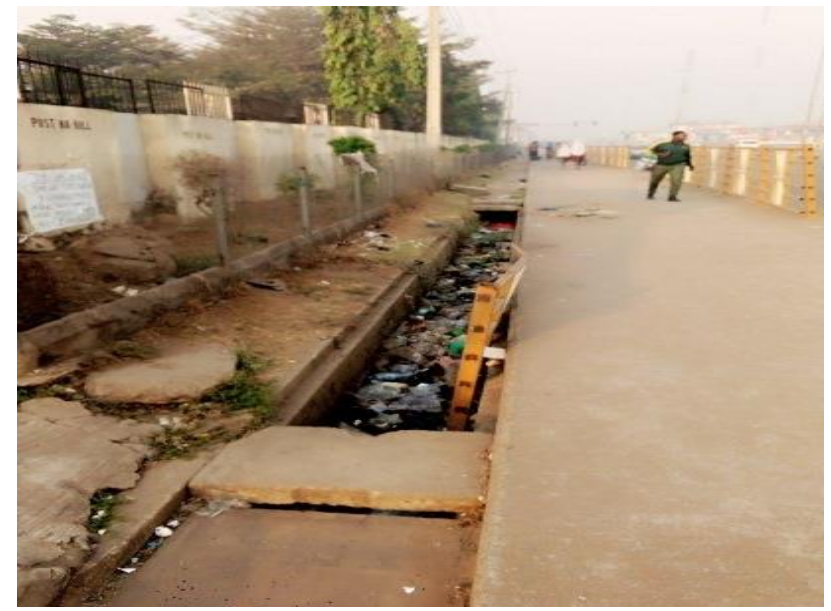

Fig 1: Picture showing drainage channel beside cathedral along oba adesida road, Akure. Authors field report (2021)

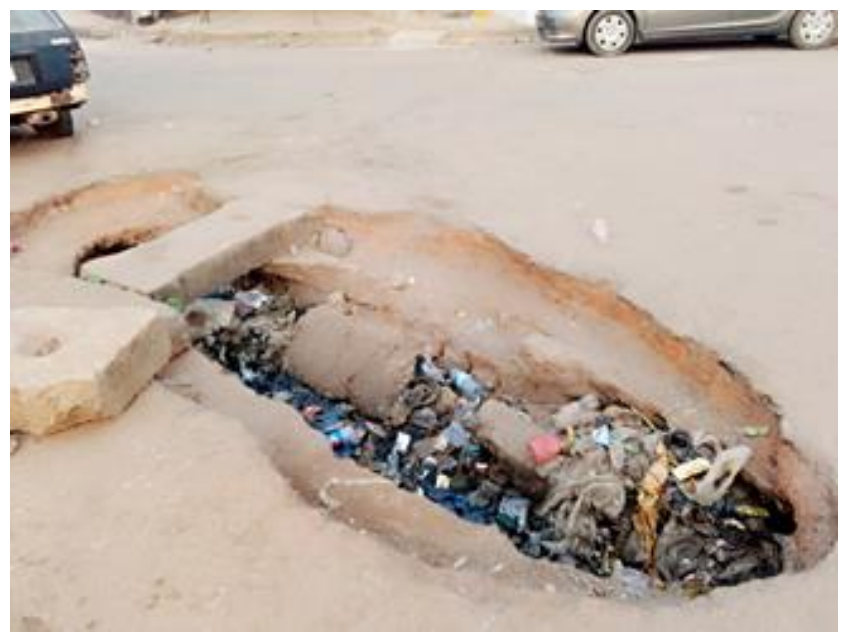

Fig 2: Picture showing damaged drainage at the middle of the road along ljemikin community, Akure Authors field report (2021) 
"Fig" 1 shows the provision of drainage channels to control neighborhood and state storm water systems. Storm water is the unwanted water resulting from precipitation around the building and the entire city. These drainage channels were noted to be successful in some areas of the city in effectively eliminating the volume of storm water runoffs, delivering its content into the nearby rivers, and avert flooding. However, the absence of these drainage channels in other areas of the city, the collapse or blockage of available once as seen in fig 2, is a significant setback to implementing green strategies for storm water and landscape sustainability Akure.

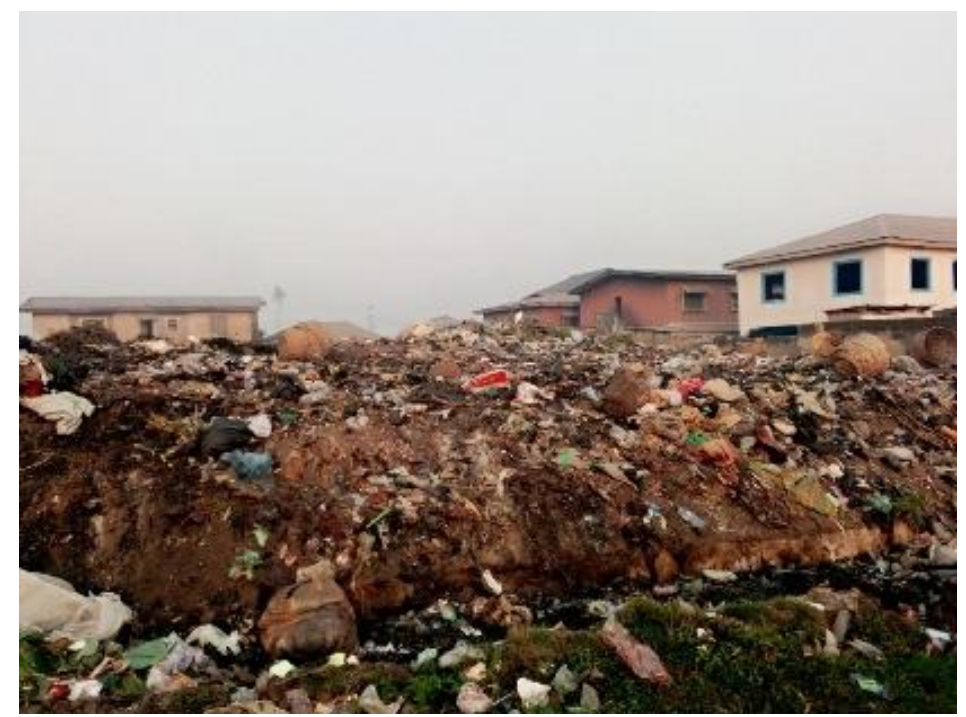

Fig 3: Picture showing a refuse dump site at ljemikin community, Akure Authors field report (2021)

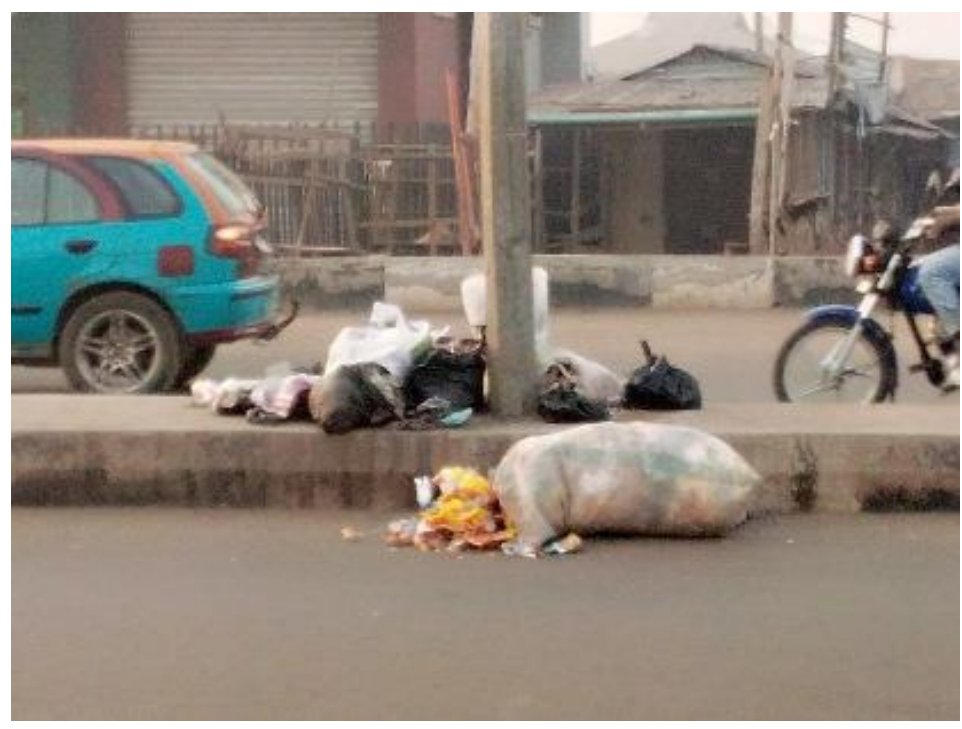

Fig 4: Picture showing a refuse dump at the middle of the road at Arakale, Akure. Authors field report (2021)

Furthermore, in addition to the identified challenges discussed above, plates 3 and 4 show another area of concern for the attainment of sustainable city landscape development of the study area is refuse control, a nexus to storm water control. Akure being a city capital is notorious for its poor refuse waste management system. Indiscriminate refuse dumpsites, as seen in plate 3 and the concomitant dumping of refuse by the roadside at the city center, is a continuous occurrence within and all over the city of Akure. Worthy of note, however, is the effort made by the Ondo State government for the control of waste management in the city through the establishment of a waste management board. Among the board's mandates is the distribution of waste bins to homes and selected public places to check the habit of dropping off refuse by the roadside, usually at the wee hour of the day, as shown in fig 4 . 


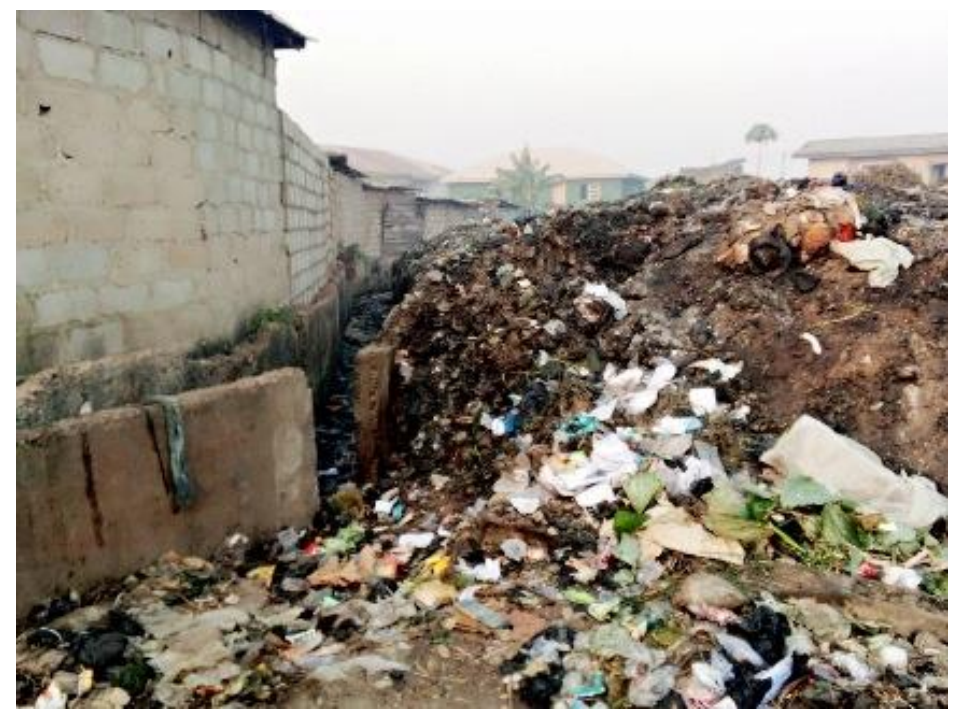

Fig, 5: Picture showing a refuse dump and the blockage of drainage channels at ijemikin community market, Akure. Authors field report (2021)

Refuse control plays a vital role in the management of storm water in the world. This is because refuse is notable in the blockage drainage channels in Nigeria, as seen in fig 5.

Furthermore, there must be community participation in the implementation value chain for any Gl strategy to be successful. First, the people must own it; secondly, it must create employment opportunities for the youth, who will serve as a watchdog in the implementation. Thirdly, these youth vanguards will serve as a crusader who will assist the government in disseminating information to the people about the goal of a cleaner city through public waste management control. Hence, a combination of these approaches will help implement the Gl strategy for effective landscape sustainability in the city of Akure.

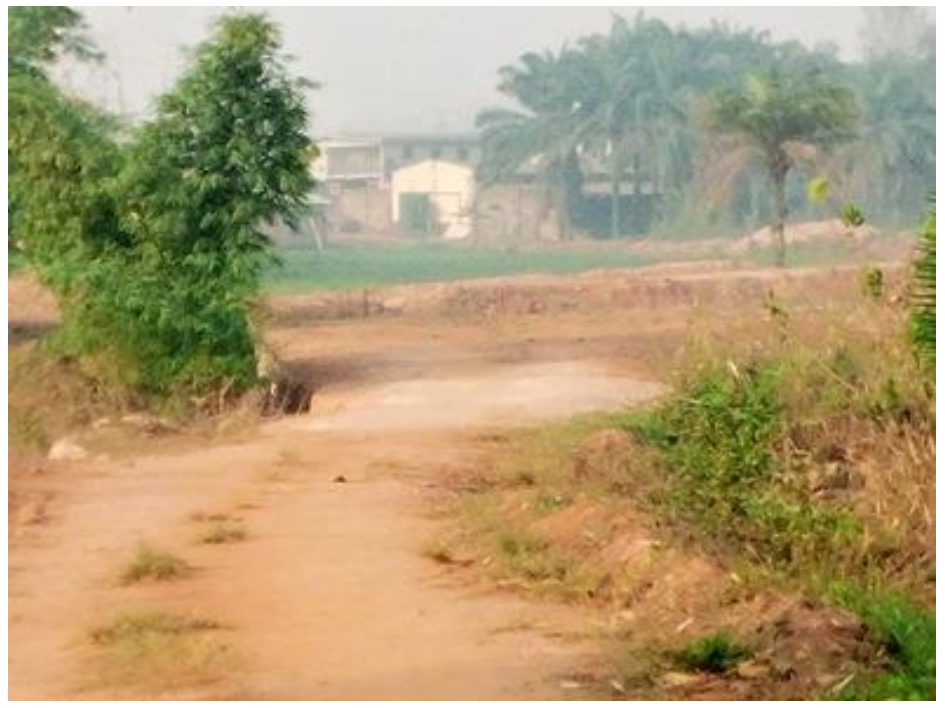

Fig, 5a: picture showing ongoing land reclamation opposite Ade-supa hotel Akure. Authors field report (2021) 


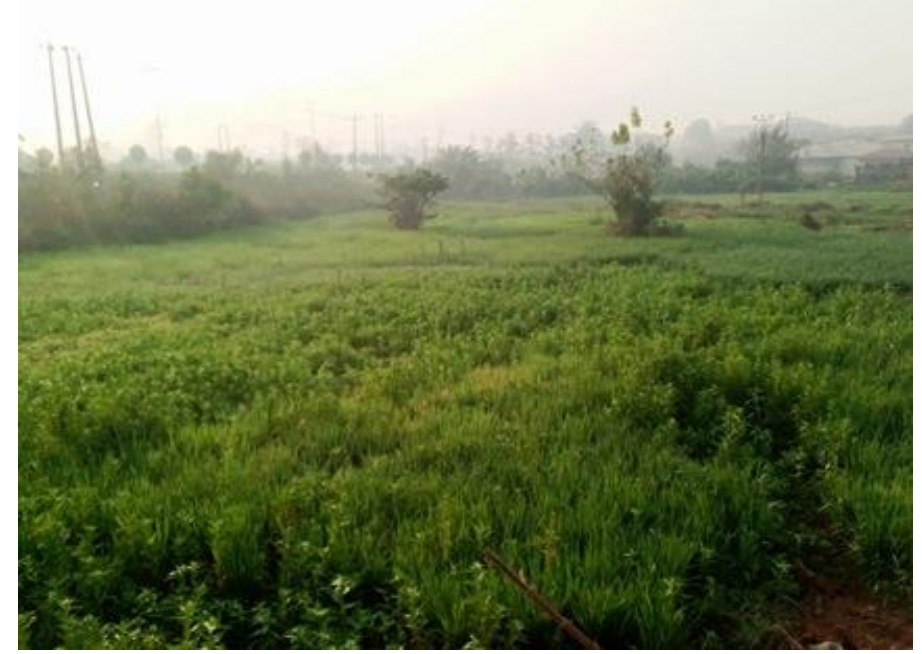

Fig, 6b: Original state of the green belt under reclamation opposite Ade-supa hotel Akure. Authors field report (2021)

Another issue affecting the implementation of the GI in Akure Ondo State is the ineffective enforcement of critical environmental management initiatives. Suffice to say, government altitude to legislation and enforcement is still at a low ebb in Nigeria compared to developed countries. Consequently, further site observation shows the presence of environmental violators everywhere in Nigeria; as seen in plate 4, a robust government policy will curtail the menace; violators or offenders are severely punished, doing so will ensure others are discouraged. For instance, plate $7 \mathrm{a}$ and $7 \mathrm{~b}$ show an ongoing land reclamation program along Oba-Adesida Road opposite Ade-Supa hotels. This activity gave credence to another failure of the government as a first-line regulator of the environment. It is worthy of note that, despite the length of time the reclamation has commenced, no contravention notice has been issued and the collaborators brought to justice, despite delineating the zone as a green belt for storm water -management. Thus, sincerity of purpose in government policies and timely implementation of the strategic plan on environmental control is vital for achieving a sustainable landscaped environment.

\section{CONCLUSION AND RECOMMENDATIONS}

This study was on $\mathrm{Gl}$ as a tool for storm water management. The study revealed that despite the renowned implementation of Gl strategies for storm water management in recent times, the implementation is still very poor in the area of study. Evident from the findings is the inappropriate disposal of waste, constructed water channels across the study area been loaded with waste. Hence, the challenge of flooding arising from storm water runoffs. Based on these findings, this study recommends that conscious effort must be made to engage stakeholders effectively in environmental management, such as government agencies saddled with responsibilities to do their job promptly. Secondly, environmental experts must continually give awareness through periodic symposia to educate the populace on the danger of poor storm water management to their wellness. Lastly, the people must own the initiative through full participation in implementation and even enforcement for any meaningful success to be achieved. More so, a holistic, simplified and cost-effective implementation plan is necessary for the overall benefit of $\mathrm{Gl}$ to be harnessed in solving Nigerian environmental challenges.

\section{REFERENCE LIST}

Adeleke, E.A and Olabode, A.D. (2017). Statistical Analysis of Rainfall Trend in Akure, Ondo State, Nigeria. Analele Universităţii Din Oradea, Seria Geografie, 1, 114-121.

Artmann, M., Kohler, M., Meinel, G., Gan, J. and loja, I.C. (2019). How smart growth and green infrastructure can mutually support each other-A conceptual framework for compact and green cities. Ecol. Indic. 96, 10-22.

Barbosa, A.E., Fernandes, J.N. \& David, L.M. (2012). Key issues for sustainable urban stormwater 
management. Water research, 46(2012), 6787-6798.

Bates, A. J., Sadler, J. P., Greswell, R. B. and Mackay, R.( 2015). Effects of varying organic matter content on the development of green roof vegetation: a six-year experiment. Landscape and Urban planning, 135, 22-31, https://doi.org/10.1016/j.landurbplan.2014.11.010

Bevilacqua, P., Mazzeo,D., Bruno, R. and Arcuri, N. (2016). Experimental investigation of the thermal performances of an extensive green roof in the Mediterranean area: Energy and Buildings, 122, 63-79, https://doi.org/10.1016/j.enbuild.2016.03.062.

Calheiros, C. S. C. and Stefanakis, A. I. (2021). Green Roofs Towards Circular and Resilient Cities. Circular Economy and Sustainability.

Cook, E.A. (2007). Green Site Design: strategies for storm water management. Journal of green building 2(4):46-56.

Demuzere, M., Orru, K., Heidrich, O., Olazabal, E., Geneletti, D., Orru, H., Bhave, A.G., Mittal, N., Feliu, E., and Faehnle, M. (2014). Mitigating and adapting to climate change: Multi-functional and multi-scale assessment of green urban infrastructure. J. Environ. Manage. 146, 107-115.

Derkzen. M.L., van Teeffelen. A. J.A.\& Verburg. P.H. (2017). Green infrastructure for urban climate adaptation: How do residents' views on climate impacts and green infrastructure shape adaptation preferences? Landscape and Urban Planning, 157 (2017), 106-130.

European Environment Agency (EEA) (2011): Green Infrastructure and Territorial Cohesion. The concept of green infrastructure and its integration into policies using monitoring systems. EEA Technical Report No 13/2011. Luxembourg: Publications Office of the European Union, 2011.

Feitosa, R.C., Wilkinson, S. (2016). Modelling green roof stormwater response for different soil depths: Landscape and Urban planning, 153, 170-179, https://doi.org/10.1016/j.landurbplan.2016.05.007.

Forest Research (2010). Benefits of green infrastructure. Report by Forest Research. Forest Research, Farnham.

Lafortezza, R., Davies, C., Sanesi, G., and Konijnendijk C.C. (2013). Green Infrastructure as a tool to support spatial planning in European urban regions. iForest 6: 102-108.

Liu,W., Chen,W.\& Peng, C. (2014). Assessing the effectiveness of green infrastructures on urban flooding reduction: A community scale study. Ecological Modelling, 291, 6-14, https://doi.org/10.1016/i.ecolmodel.2014.07.012.

McCoullgh, M. B., Martin, M. D. and Sajady, M. A. (2018). Implementing Green Walls in Schools. Perspective article, Front. Psychol. https:doi.org/10.3389/fpsyg.2018.00619.

McPhearson, T., Pickett, S.T.A., Grimm, N.B., Niemelä, J., Alberti, M., Elmqvist, T, Weber, C., Haase, D., Breuste, J. and Qureshi, S. (2016). Advancing Urban Ecology toward a Science of Cities. BioScience 66, 198-212.

Pakzad. P \& Osmond. P (2016). Developing a sustainability indicator set for measuring green infrastructure performance: Procedia - Social and Behavioral Sciences, 216, 68 - 79.

Shafique,M., Kim, R. \& Rafiq,M. (2018). Green roof benefits, opportunities and challenges - A review: Renewable and Sustainable Energy Reviews, 90, 757-773.

Tóth, A., Štěpánková, R. and Feriancová, L. (2016). Landscape Architecture and Green Infrastructure in the Slovak Countryside. Issued by the Czech University of Life Sciences Prague as a peer-reviewed scientific monograph. 